\title{
LIMITATIONS OF ATTENDANCE MONITORING AS A SINGULAR TOOL FOR MOTIVATING STUDENTS' ACADEMIC ENGAGEMENT: THE CASE STUDY OF ONE OVERSEAS STUDENT
}

\author{
MUKE M FERGUSON, FLETCHER M PHIRI
}

\begin{abstract}
:
Background, aims \& objectives: Attendance monitoring is very important in attaining students' academic engagement which in turn improves students' academic performance at university level. Visa tied students face different criteria in terms of attendance monitoring and the level of recorded study contact points or hours. One area of action research that such requirement raises is to investigate whether quantitative attendance translates into quantitative student outcomes in terms attempts to assignment or exam success at study-unit or module level and the final overall classification of academic-degree attained.

Methodology: We use the case study approach, where we present a case study of an overseas student who presented with an excellent quantitative attendance record that had not translated into academic engagement or success. The aim is to determine whether and if so what intervention could bridge the gap between quantitative attendance and academic performance.

Findings: For the case study subject we found that qualitative consultative management helped to resolve the observed disconnect between quantitative classroom attendance and quantitative student academic outcome.

Conclusions and Implications: We conclude that monitoring quantitative engagement, in the form of quantitative class attendance, is singularly unlikely to be a useful tool that can be used to gauge students' academic engagement. For the case studies qualitative interaction with academic staff held the key to the student achieving the required academic engagement that produced noticeable quantitative academic outcomes.

The insight gained from this case study may be of interest to institutions that especially serve overseas students who, by virtue of UKVI statutory requirements and institutional regulatory requirement are mandated to present with a minimum quantitative "class" attendance record whence this does not necessarily translate to a similarly good quantitative academic outcome in terms of grade of degree and sometimes, time to completion of their studies.
\end{abstract}

\section{Keywords:}

Academic engagement; overseas student; UKVI; visa tied students; attendance monitoring; student pastoral care; consultation management

JEL Classification: 129, 121, 128

\section{Authors:}

MUKE M FERGUSON, Glyndwr University, London, UK \& Centre for Human Development Studies, UK:, United Kingdom, Email: m.ferguson@glyndwr.ac.uk 
FLETCHER M PHIRI, Great Lakes Open University (Uganda) \& Centre for Human Development Studies, UK, United Kingdom, Email: phiri@examsolutionprovider.com

\section{Citation:}

MUKE M FERGUSON, FLETCHER M PHIRI (2016). Limitations of attendance monitoring as a singular tool for motivating students' academic engagement: The case study of one overseas student. International Journal of Teaching and Education, Vol. IV(1), pp. 16-25., 10.20472/TE.2016.4.1.002 


\section{Introduction and Background}

The higher Education sector in United Kingdom (UK) has been undergoing structural changes over the past few years both in relation to direct government funding of Higher Education Institutions (HEls) and the way these institutions can generate funds. Overseas students remain the staple of postgraduate courses in many UK HEls; recent data from the United Kingdom Higher Education Statistical Agency (HESA) put the proportion of non-EU postgraduate students at $40 \%$ to $50 \%$ (Higher Education Policy Institute and The British Library, 2010). Thus the need to attract new students and mitigating attrition by retaining undergraduate students to study completion, and even transfer to higher level study including research is now an important operational consideration for many UK HEls as evidenced by the multitude of related policy documents flowing from a number of strategic committees of many UK HEls (Buckinghamshire New University, 2014; van Stolk et al. 2007; Dodgson \& Bolam, 2002). Attracting students to postgraduate studies and as importantly mitigating attrition at all level of university study is not only important to the financial performance of UK HEls but is key to maintaining UK's competitive advantage in the modern knowledge led global economy. While, HEl's can and do recruit students directly onto postgraduate courses, a large number of postgraduate students are transfers from undergraduate courses. A rough estimate is that $50 \%$ of new postgraduate students are transfers who get first or second class degrees at undergraduate study (Higher Education Policy Institute and The British Library, 2010).

It is postulated that highly engaged students are more likely to succeed academically. For overseas students, this means that they will be able to complete their studies within their initial visa period, and if necessary, as is the case, transfer to postgraduate study and similarly complete their postgraduate study as prescribed. Taylor and Parsons (2011) reviewed the literature on student engagement and noted that while study in relation to student engagement has seen a shift from focusing upon disengaged learners, (meaning those who are not learning), to engaged learners, (those who are learning) and concluded that there is now recognition to focus on student's learning needs. Study of student engagement was mainly focussed in middle and high school arena which was seen as stepping stone to engagement at HEI study. Strategies studied have included, social engagement of students from socioeconomically disadvantaged backgrounds and seen to be at risk of drop-out, through 
managing classroom behaviours to the current focus of enhancing students' abilities to learn how to learn. As Taylor and Parsons (2011) note "Student engagement has become both a strategic process for learning and an accountability outcome unto itself." (p.4). Having noted this student engagement as a concept is multifaceted, several types reported in the literature include; academic, cognitive, intellectual, institutional, emotional, behavioural, social, psychological, etc. and it is difficult to establish which aspects of engagement translate to learning or academic success. Taylor and Parsons' (2011) review reported that measures predominantly focussed on quantitative measures such as attendance but not student engagement in learning; defined as interest, time on task, and enjoyment in learning. Indeed current strategies take into account support for student engagement in learning both in and beyond the classroom.

\section{The case study:}

Here we present a case study of Gil (pseudonym used in order to preserve confidentiality), a 24 year old non-EU student, who on all accounts had dissociated from all learning-related activities. He, (where the male pronoun is used as an inclusive gender), was only attending class in order to comply with University rules that mandated an attendance record of at least $80 \%$ because a failure to meet this attendance level would have resulted in Gil being reported to the United Kingdom Visas and Immigration (UKVI) Agency for breaching his conditions for leave to remain in the United Kingdom (UK) on his study visa - a situation that might have led him to losing his valued part-time job, and maybe also resulted in him being deported from United Kingdom back to his home country. In consideration of Taylor and Parsons (2011) Gil's engagement was simply instrumental engagement designed to comply with an administrative requirement whether UKVI or institutional.

\section{Importance of initial assessment of student needs}

One of the authors first met Gil during his first lesson. Since most of the students in the cohort were non-EU students for whom English is a second language, the author considers it good practice to assess a new class's English competency during the first session with them. On this occasion the class size was small enough not to require sampling and therefore each student was asked to introduce themselves by saying something 'special or interesting' about themselves. It is also important to be mindful 
that reciprocity encourages self-disclosure (Burkard et al., 2006; Patterson, 1997; Owuamanam, 1989), and the lecturer started the process by asking them to talk about themselves. On this occasion, this approach appeared to calm the students' nerves. The effect of this was that many students adopted the format that the lecturer had used during their contribution. When it was Gil's turn, it was noted that his English grammar was generally good and his presentation was coherent and largely well structured. Thus, the subsequent discovery of his poor academic performance could not have been consequent to poor English language skills.

\section{Student centric learning}

In consideration of Cant and Cooper (2011) who notes that briefing in the sense of reflecting on learning episodes is an important part of education, when all the students had contributed, a few students, of varying ability as gleaned from their presentations, were asked to share their feelings in relation to their presentations. Most admitted that they found the exercise quite interesting; both because they learned something about other students and of course by the fact that they had been able to tell the others about themselves and in some cases share their experiences and raise a few laughs. It can be said that this was a useful exercise, and one that could be utilised in most first-contact situations between the teacher and a class of students.

Importantly, this 'individual' presentation is a student led, student-centric, form of learning that positions the individual as the centre of their individual learning; in this case in the all-important presentation skills as 'presenting' is a feature not only of most of the modules in the curriculum delivered in many HEls, but it is also a feature of multiagency and team working in modern professional practice (DfSE, 2004); a factor further noted in Atkinson et al.'s (2001) study, which reported that presentation accounts for $21 \%$ of multiagency team meetings.

Following a short lecturing session the students were asked to use the lecture notes and online resources to write an individual piece of work which the lecturer collected and assessed. This exercise often helps the lecturer to formulate a plan of support in terms of (English) language and other support needs and how to deliver module content. It is invaluable to support students as they carry out their tasks both because you gain more insight into the students' abilities and/or their understanding and 
interpretation of the learned concepts but also because the student feels supported. However, observation may have the negative effect of intimidating the students. Indeed there is a case for the lecturer leaving the class and letting the students learn from each other (Jones, 2007). Nevertheless, as the lecturer walked round the class, observing the students working, they noticed that Gil was simply sitting down with his arms crossed. When asked whether he needed help, Gil informed the lecturer that he had failed his first three modules, both on first submission and on resubmission and he had not submitted any work for his second-semester assignments as he knew he would not get any 'certificate' for completing the course. The lecturer was concerned about this and felt uncomfortable that Gil was discussing the issues in front of other students, and offered that the discussion take place in private later, but Gil smiled and added that all the other students knew about his situation. Nevertheless, he stopped and agreed to discuss the matter later in private.

\section{Establishing confidentiality boundaries in support provision}

While it can be argued that Gil was entitled to say whatever he wanted to say in front of other students, there are a range of issues related to respecting the individual student's confidentiality when discussing matters that verge on the personal. But most importantly, when Gil quickly also added that other members of staff, (he mentioned their names), knew about his non-participation in learning activities, the lecturer felt that it was important to negate the impression that members of staff are complicit in such behaviour. The author informed Gil that 'just sitting in class' without participating in learning activities was not an option and that one of the duties of coming into class was participation. In the event Gil completed and handed in his completed work. Afterwards the lecturer spoke with Gil and informed him that his feelings about his academic progress would be raised with the Programme Lead.

Although, most of the students, including Gil, produced reasonably good descriptive pieces of written work, a few of the students only managed to write two or three sentences; whereas they had been asked to write at least half a page of an A4 sheet. It was evident that about a quarter of the students would benefit from academic writing support. However, at that point academic writing support was quite patchy; a situation that needed attention, and was soon rectified with the appointment of dedicated academic support personnel. 


\section{Some factors impacting on student engagement}

While writing this account, we are conscious that most of our non-EU, overseas, students associate with, and live with, people who speak their mother language which is often not English. Furthermore, they often have little opportunity to use English outside of university. The memory of lecturer's undergraduate experience is that many overseas students by then used their university's accommodation office to obtain lodgings with 'English' families who were happy to offer accommodation to overseas students. The students almost universally acknowledged the benefit of living-in with an 'English' family by way of improving their English language skills; much like au-pairs do. However, again at present this form of accommodation arrangement currently university has no accommodation officer to coordinate the activity of putting students in touch with 'English' speaking families - it is an issue the lecturer hoped to raise at the following staff meeting, although it was suspected that funding the post would be an issue for management. However, other options such as engaging a willing accommodations agency may be considered - this is a possible business opportunity or an area that student welfare could have considered.

A meeting was later convened with Gil and four members of the academic staff including the co-author. Considering the form of the meeting, the lecturer later mused whether Gil might have felt intimidated during the meeting; after all he was all alone against four members of staff. Prior to the meeting, the lecturer had not told Gil that he could, if he wished, ask a friend or the class representative to accompany him to the meeting. Having noted this, it didn't seem that Gil was intimidated or over-awed by the meeting. He was calm and candid. He intimated that he was only attending class to meet the attendance requirements. When he was directly asked in relation to his parttime work, he acknowledged that he was happy with his work and that he was able to pay his bills, and have a little money left over to put into savings. Also he noted that he was investigating opportunities to work in the Middle East or in the British Army. We were all struck by his candour and in a sense naivety and innocence. Using the backdrop of his proposed future plans for professional practice, the Programme Lead impressed upon Gil the importance of getting at least some 'pass' modules on his results transcript. We were glad that the Programme Lead was reiterating and reinforcing what Gil had been told before the meeting. Often repeating a message, especially by different people lends its credibility. Gil offered to work hard in order to 
pass the modules he was then taking. All of us offered to support him in his efforts and the meeting concluded.

After Gil had left, two colleagues observed that Gil had made similar promises before and his promises had come to nothing. We spent some time analysing the support that had been offered to Gil; in particular we noted that support that is perceived as confrontational or 'blame-the-student' is particularly unhelpful. However, from the fact that Gil's work was assessed to be above the class average score when assess led the lecturer to conclude that that Gil's English language skills were at an appropriate level for him to engage with learning. Furt5hermore, the fact that he could produce good work under seemingly strict, controlled, (timed), class environment demonstrated his potential, willingness and ability to produce good quality work; and by extension his potential for academic success; if only he could be properly supported.

\section{Outcome of Gill's support provision}

In the following weeks, Gil continued to attend his classes. He often commented that he would have done well in his previous modules if he had received the encouragement and support that he was now receiving. However, like all social situations, the complexity of Gil's circumstances are such that it is difficult to judge whether it was the support that he was receiving, or indeed the perception that support was now readily available to him, or whether it was simply the meeting that has motivated Gil. Whatever the motivating factor, it appears evident that the catalyst was Gil's realisation that he could yet get some form of 'qualification' out of his studies in United Kingdom. This raises the issue of exit points and transcripts of results. Firstly, it may be useful for courses to have different (qualification) exit points for students who do not successfully complete all their modules; and this happens on most courses in most Higher Education Institutions (HEls) in United Kingdom. Secondly, the value of the transcripts of results needs to be emphasised to students - both in terms of transferable credits and for other purposes including employability - it is important for students not to regard their success in HEls study as an ALL (pass all the modules and attain the course-certificate) or NOTHING (fail to obtain the course-certificate) situation. In this regard, information about exit points and transcripts of results and the value of individual credits of modules should be widely circulated to students; maybe in a student/course information pack. 
After the end of term, Gil passed both the two modules he had studied albeit in the early $52 \%$ and $54 \%$; (where the pass mark is set at $40 \%$, credit set at $60 \%$ ). This left the authors with a sense of satisfaction and achievement. However, it also left us wondering what Gil might have achieved had he received appropriate pastoral care and support early in his studies.

\section{Concluding Remarks}

This case study brings attention to the importance of pastoral or a deliberate one-toone tutoring system to ensure that student progress and their academic needs are closely monitored and individually tailored qualitative support is given; it would seem student motivation and success is just a stone's throw away from such qualitative interaction with academic staff; as it is this personalised process that appears to be the key to the student achieving the required academic engagement that produces noticeable quantitative academic outcomes. We are glad that, despite resource and time limitations, as a team we now have a robust pastoral care system in place to support our students as best as we can to ensure that they thrive, even against what they may perceive as insurmountable obstacles and sometimes their disparate (nonacademic) motivations for coming to the United Kingdom.

This case study is only one illustration where qualitative intervention produced a positive quantitative academic outcome measure. However, as noted earlier in this discussion the study of engagement and academic outcome and the link between the two is huge and is undergoing development and there is need for research into how the now widely acknowledged qualitative dimensions of student engagement is related to pastoral care and socialising link to more traditional, quantitative measures of engagement in the form of student outcomes and, particularly for learners who have limited time to completion.

\section{References}

Atkinson, M., Wilkin, A., Stott, A., Doherty, P. and Kinder, K. (2001). Multiagency working: a detailed study. Slough, UK: National Foundation for Educational Research Accessed 28/04/2012 @ http://www.nfer.ac.uk/nfer/publications/CSS02/CSS02.pdf

Buckinghamshire New University (2014). Student Retention Strategy 2014-2017. UK Buckinghamshire New University: Student Services Directorate

Burkard, A.W., Knox, S., Groen, M., Perez, M. and Hess, S.H. (2006). “European American Therapist 
Self-Disclosure in Cross-Cultural Counseling". Journal of Counseling Psychology, Vol.53, No. 1 Accessed 28/04/2012 @

http://epublications.marquette.edu/cgi/viewcontent.cgi?article $=1011 \&$ context=edu fac\&seiredir=1\&referer=http\%3A\%2F\%2Fwww.google.co.uk\%2Furl\%3Fsa\%3Dt\%26rct\%3Dj\%26q\%3De uropean\%2520american\%2520therapist\%2520self-disclosure\%2520in\%2520crosscultural\%2520counseling\%26source\%3Dweb\%26cd\%3D2\%26ved\%3D0CDAQFjAB\%26url\%3D http\%253A\%252F\%252Fepublications.marquette.edu\%252Fcgi\%252Fviewcontent.cgi\%253Farti cle\%253D1011\%2526context\%253Dedu fac\%26ei\%3DIGqcT7iCGLGZ0QWxk4XmDg\%26usg\% 3DAFQjCNF SOwXJZ4zAPfae5phwbtRvPc5gg\#search=\%22european\%20american\%20therapi st\%20self-disclosure\%20cross-cultural\%20counseling\%22

Cant, R.P. and Cooper, S.J. (2011). "The benefits of debriefing as formative feedback in nurse education". Australian Journal of Advanced Nursing, Vol 29, N0.1, pp. 37-47 accessed on line on 28/04/2012 @ http://www.ajan.com.au/Vol29/29-1 Cant.pdf

DfSE (2004). Every child matters: change for children. Nottingham, UK: Department for Education and Skills, HMSO Accessed 29/04/2012 @ https://www.education.gov.uk/publications/eOrderingDownload/DfES10812004.pdf Higher Education Policy Institute and The British Library (2010). Postgraduate Education in the United Kingdom. British Library, UK

Jones, L. (2007). The student centred classroom. Cambridge. UK: Cambridge University Press.

Accessed 28/04/2012 @ http://www.cambridge.org/other files/downloads/es//booklets/JonesStudent-Centered.pdf

Owuamanam, T.O. (1989). "A review of correlates of clients' self-disclosure in counselling relationships". Ilorin Journal of Education, Vol.9, pp.16-25 Accessed 28/04/2012 @ http://www.unilorin.edu.ng/nagpur/unilorin/journals/education/ije/dec1989/A\%20REVIEW\%200F \%20CORRELATE\%200F\%20CLIENTS.pdf

Patterson, C.H. (1985). The therapeutic relationship (excerpt). Monterey, CA: Brooks/Cole

Accessed 28/04/2012 @ http://www.sageofasheville.com/pub downloads/THERAPIST SELFDISCLOSURE.pdf

Taylor, L. and Parsons, J. (2011). Improving Student Engagement. Current Issues in Education, 14(1). Accessed 16/10/2015 @ http://cie.asu.edu/ojs/index.php/cieatasu/article/viewFile/745/162 Dodgson, $\mathrm{R}$ and Bolam, $\mathrm{H}$ (2002). Student retention, support and widening participation in the North East of England. Universities for the North East, UK

Van Stolk, C, Tiessen, J, Clift, J and Levitt, R (2007). Student Retention in Higher Education Courses: International Comparison. Rand Corporation 